\title{
Characteristics of Guillain-Barre Syndrome Patient Underwent Hyperbaric Oxygen Therapy at Lakesla 2016-2019
}

\author{
Ni Komang Sri Dewi Untari ${ }^{1,2,3 *}$, Kurnia Kusumastuti ${ }^{4}$, Guritno Suryokusumo ${ }^{5}$, I Ketut Sudiana ${ }^{6}$ \\ ${ }^{1}$ Department of Hyperbaric, Drs. Med. Rijadi S. Phys. Naval Health Institute, Surabaya, Indonesia; ${ }^{2}$ Department of Neurology, \\ Faculty of Medicine, Hang Tuah University, Dr. Ramelan Navy Hospital, Surabaya, Indonesia; ${ }^{3}$ Outside Lecturer, Hyperbaric \\ Medicine, Basic Medical Science, Master Program, Airlangga University, Surabaya, Indonesia; ${ }^{4}$ Department of Neurology, Faculty \\ of Medicine, Airlangga University, Surabaya, Indonesia; ${ }^{5}$ Department of Hyperbaric, Faculty of Medicine, Pembangunan Nasional \\ University, Jakarta, Indonesia; ${ }^{6}$ Department of Pathology Anatomy, Faculty of Medicine, Airlangga University, Surabaya, Indonesia
}

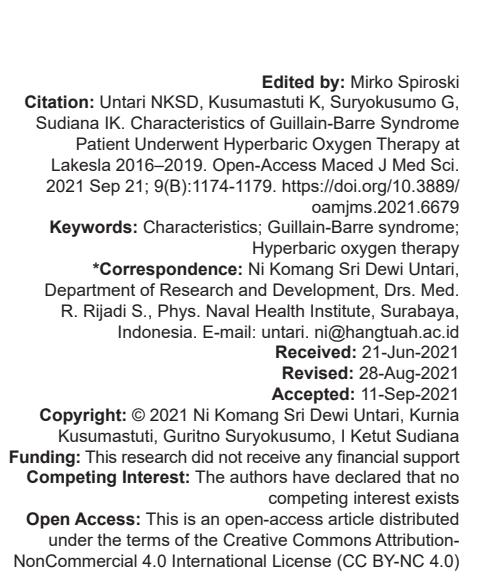

\section{Abstract}

BACKGROUND: Guillain-Barre syndrome (GBS) is considered an acute immune-mediated monophasic illness. Standard therapy includes intravenous immunoglobulin (IVIG) and/or plasmapheresis. Yet, long-standing disability remains a problem. In Indonesia, the availability and cost of these therapies are constraints.

AIM: To show the capability of hyperbaric oxygen (HBO2) therapy in GBS patients who did not undergo standard therapy. $\mathrm{HBO} 2$ also provides healing in patients who experience delays in therapy.

METHODS: Data included identity, demographic, social history, current disease history, disease progression and therapies used. Data were displayed in the form of tables and graphs.

RESULTS: Twenty-five GBS patients underwent HBO2 from 2016 to 2019. The majority of patients were males aged 20-30 years, triggered by preceding diarrhea. After approximately three to ten days following $\mathrm{HBO} 2$, they felt their first positive changes. They walked with assistance after two to three weeks receiving HBO2 and without assistance after four to 12 weeks receiving $\mathrm{HBO} 2$.

CONCLUSION: HBO2 administration show clinical improvement in GBS patients. HBO2 is expected to become an adjuctive therapy for GBS patients in Indonesia.

\section{Introduction}

Guillain-Barre syndrome (GBS) is a group of clinical syndromes with acute onset of polyradiculoneuropathy - axonal or demyelinating - after an autoimmune-mediated process. GBS is characterized by weakness of the locomotor system and loss of tendon reflexes [1], [2]. It is suggested that the pathophysiology of GBS involves a cross-reaction between autoimmune antibodies and inflammatory cells with epitopes on peripheral nerves, roots, or plexuses, leading to demyelination, axonal damage, or both [3]. The immune response is thought to be triggered by various antigenic stimuli 1-3 weeks before neuropathic symptoms, particularly respiratory and gastrointestinal infections in approximately two-thirds of people with GBS. Campylobacter jejuni, an important cause of diarrheal disease, is said to be the most common and is associated with slower recovery and severe residual disability due to predominant axonal degeneration [4], [5], [6]. Other pathogens identified included cytomegalovirus, Epstein-Barr virus, mycoplasma pneumonia, and
Haemophilus influenzae [7], [8], [9]. GBS was also observed after vaccination for rabies and swine influenza [10], and potentially associated with Zika virus infection [11], [12], [13].

The estimated incidence rate of GBS in Europe and North America has been estimated $0.8-1.9$ cases per 100,000 people [14]. The estimate GBS annual incidence rate has increased by $20 \%$ for every 10-year increase in age [14]. It was reported that GBS incidence rate was $0.6 / 100,000$ per year in children and 2.7/100,000 in elderly people aged 80 and over; GBS is slightly more frequent in males than in females [15]. The incidence rate of GBS in Indonesia is not known. In Lakesla, Indonesia, there were 48 cases of GBS from various types between 2010 and 2011, which showed an increase of $10 \%$ compared to the previous year [16].

Age, preceding infections, clinical features, syndromes and signs during hospitalization, as well as early recognition and treatment were found to be very important in the long-term prognosis of GBS [17], [18]. Intravenous immunoglobulin (IVIG) and plasma exchange (PE) have been used to hasten 
recovery [19], [20], and yet the reported mortality rate ranging between $1 \%$ and $18 \%$ [21], [22].

At our institution, we have used hyperbaric oxygen therapy (HBO2) as adjuvant therapy for GBS. HBO2 is defined as a treatment in which a patient intermittently breathes $100 \%$ oxygen while the treatment chamber is pressurized to a pressure greater than sea level (1.0 atmosphere absolute, ATA) [23]. Acute GBS is one of the non-emergency indications for $\mathrm{HBO} 2$ [23]. HBO2 seems to give promising results for GBS. The purpose of writing this article is to present the characteristics of GBS patients undergoing $\mathrm{HBO} 2$ at Lakesla, Surabaya, Indonesia.

\section{Materials and Methods}

This study took the entire reachable population of GBS patients undergoing $\mathrm{HBO} 2$ therapy from 2016 to 2019 . We studied all patients with a primary discharge diagnosis of GBS (ICD-10 code G61.0) [24] and diagnosis of rehabilitation (ICD-10 code Z50.X) [24] between 2016 and 2019. The patients were identified from the Lakesla registration center. All patients underwent neurological clinical examinations, including motor, sensory, physiological reflexes, and pathological reflexes. However, cerebrospinal fluid, immunoglobulin, and electromyographic examinations were incomplete due to limited funds. Advances in neurological clinical improvement were evaluated after the patients received 10 treatments of $\mathrm{HBO} 2$ (referred to as one package). The ethical clearance of this study was obtained from Lakesla.

\section{Results}

There were 25 GBS patients underwent $\mathrm{HBO} 2$ from 2016 to 2019. Table 1 shows that the majority of GBS patients were male $(72 \%)$. The majority of male patients were between 20 and 30 years old (27.78\%), whereas the majority of female patients were between 30 and $40(42.86 \%)$.

Table 1: Demographic characteristics of study subjects

\begin{tabular}{|c|c|c|c|c|c|c|}
\hline \multirow[t]{2}{*}{ Characteristics } & \multicolumn{2}{|c|}{ Males } & \multicolumn{2}{|c|}{ Females } & \multicolumn{2}{|l|}{ Total } \\
\hline & Freq. & $\%$ & Freq. & $\%$ & Freq. & $\%$ \\
\hline \multicolumn{7}{|l|}{ Age (years) } \\
\hline $0-10$ & 1 & 5.56 & 1 & 14.29 & 2 & 8.00 \\
\hline $10-20$ & 2 & 11.11 & 0 & 0 & 2 & 8.00 \\
\hline $20-30$ & 5 & 27.78 & 0 & 0 & 5 & 20.00 \\
\hline $30-40$ & 4 & 22.22 & 3 & 42.86 & 7 & 28.00 \\
\hline $40-50$ & 1 & 5.56 & 0 & 0 & 1 & 4.00 \\
\hline $50-60$ & 4 & 22.22 & 2 & 28.57 & 6 & 24.00 \\
\hline $60-70$ & 0 & 0 & 1 & 14.29 & 1 & 4.00 \\
\hline$>70$ & 1 & 5.56 & 0 & 0 & 1 & 4.00 \\
\hline Total & 18 & 100.00 & 7 & 100.00 & 25 & 100.00 \\
\hline \multicolumn{7}{|c|}{ Occupation and social status } \\
\hline TNI & 10 & 55.56 & 0 & 0 & 10 & 40.00 \\
\hline Core family of TNI & 2 & 11.11 & 2 & 28.57 & 4 & 16.00 \\
\hline
\end{tabular}

\begin{tabular}{lllllll} 
Civil service of KEMHAN & 0 & 0 & 2 & 28.57 & 2 & 8.00 \\
Private & 6 & 33.33 & 3 & 42.86 & 9 & 36.00 \\
Total & 18 & 100.00 & 7 & 100.00 & 25 & 100.00 \\
\hline
\end{tabular}

We classified the patients into four categories based on the patients' occupation and social status: The Indonesian national soldier (TNI); the core family of TNI; the civil service of the Ministry of Defense (KEMHAN), excluding the three statuses mentioned earlier; and private patients. The majority of GBS patients were TNI (40\%), particularly the navy; followed by private $(36 \%)$; core family of TNI (16\%); and civil service of KEMHAN (8\%).

Most GBS patients came to the emergency department due to progressive weakness in the form of difficulty swallowing and breathing that led to death. Around $55 \%$ of GBS patients underwent $\mathrm{HBO} 2$ at Lakesla were previously hospitalized at Dr. Ramelan Navy Hospital. A small percentage of GBS patients were a referral from other hospitals in Surabaya (in-town); outside Surabaya but in East Java Province.

Between 2016 and 2019 (Table 2), around 44\% of all patients were admitted in 2018. Approximately $48 \%$ of GBS patients were admitted at Lakesla from January to March, and the majority of them were admitted in February. The time interval from the onset of GBS to receiving $\mathrm{HBO} 2$ mostly was $1-7$ days $(32 \%)$. GBS patients who did not receive IVIG or plasmapheresis therapy generally came to Lakesla on the $3^{\text {rd }}$ day. However, patients who had received IVIG and/or plasmapheresis therapy on the first 5 days still sought $\mathrm{HBO} 2$ on the $10^{\text {th }}$ day. Four patients came after 28 days from onset of GBS since they were unaware of the advantage of $\mathrm{HBO} 2$ and they were not referred to Lakesla by their clinicians.

Table 2: Patients' hometown, frequent hospital admission and month, and the time interval between onset of GBS and receiving $\mathrm{HBO} 2$

\begin{tabular}{|c|c|c|c|c|c|c|}
\hline \multirow[t]{2}{*}{ Characteristics } & \multicolumn{2}{|c|}{ Surabaya } & \multicolumn{2}{|c|}{ Outside Surabaya } & \multicolumn{2}{|l|}{ Total } \\
\hline & Freq. & $\%$ & Freq. & $\%$ & Freq. & $\%$ \\
\hline \multicolumn{7}{|c|}{ Frequent hospital admission and month } \\
\hline \multicolumn{7}{|l|}{2016} \\
\hline October & 1 & 6.67 & 1 & 10.00 & 2 & 8.00 \\
\hline Total in 2016 & 1 & 6.67 & 1 & 10.00 & 2 & 8.00 \\
\hline \multicolumn{7}{|l|}{2017} \\
\hline January & 0 & 0 & 1 & 10.00 & 1 & 4.00 \\
\hline April & 1 & 6.67 & 0 & 0 & 1 & 4.00 \\
\hline July & 1 & 6.67 & 1 & 10.00 & 2 & 8.00 \\
\hline August & 0 & 0 & 1 & 10.00 & 1 & 4.00 \\
\hline November & 1 & 6.67 & 1 & 10.00 & 2 & 8.00 \\
\hline December & 1 & 6.67 & 0 & 0 & 1 & 4.00 \\
\hline Total in 2017 & 4 & 26.67 & 4 & 40.00 & 8 & 32.00 \\
\hline \multicolumn{7}{|l|}{2018} \\
\hline January & 0 & 0 & 1 & 10.00 & 1 & 4.00 \\
\hline February & 5 & 33.33 & 2 & 20.00 & 7 & 28.00 \\
\hline March & 0 & 0 & 1 & 10.00 & 1 & 4.00 \\
\hline July & 1 & 6.67 & 0 & 0 & 1 & 4.00 \\
\hline Forgot & 1 & 6.67 & 0 & 0 & 1 & 4.00 \\
\hline Total in 2018 & 7 & 46.67 & 4 & 40.00 & 11 & 44.00 \\
\hline \multicolumn{7}{|l|}{2019} \\
\hline January & 1 & 6.67 & 0 & 0 & 1 & 4.00 \\
\hline February & 0 & 0 & 1 & 10.00 & 1 & 4.00 \\
\hline May & 2 & 13.33 & 0 & 0 & 2 & 8.00 \\
\hline Total in 2019 & 3 & 20.00 & 1 & 10.00 & 4 & 16.00 \\
\hline Total in 2016-2019 & 15 & 100.00 & 10 & 100.00 & 25 & 100.00 \\
\hline \multicolumn{7}{|c|}{ Time interval from onset of GBS to receiving $\mathrm{HBO} 2$ (days) } \\
\hline $1-7$ & 3 & 25.00 & 5 & 38.46 & 8 & 32.00 \\
\hline $8-14$ & 4 & 33.33 & 1 & 7.69 & 5 & 20.00 \\
\hline $15-21$ & 3 & 25.00 & 4 & 30.77 & 7 & 28.00 \\
\hline $22-28$ & 0 & 0 & 1 & 7.69 & 1 & 4.00 \\
\hline$>28$ & 2 & 16.67 & 2 & 15.38 & 4 & 16.00 \\
\hline Total & 12 & 100.00 & 13 & 100.00 & 25 & 100.00 \\
\hline
\end{tabular}


GBS is usually preceded by infection and a greater number of GBS patients who underwent $\mathrm{HBO} 2$ reported that they had a history of diarrhea $(44 \%)$ and common colds (28\%) as a precursor (Figure 1). The main types of GBS patients underwent $\mathrm{HBO} 2$ were motor impairment ( $72 \%$ ), whereas $20 \%$ of GBS patients came with motor and sensory impairment. The classification was based only on neurological physical examinations with hammers, cotton, needles, and hotcold sensations. Only 2 patients (8\%) showed Miller Fisher syndrome (MFS), with double vision as the chief complaint on their initial visit. Approximately $36 \%$ of GBS patients who underwent $\mathrm{HBO} 2$ had received IVIG therapy, no patient received plasmapheresis, and $4 \%$ of the patients received corticosteroid therapy.

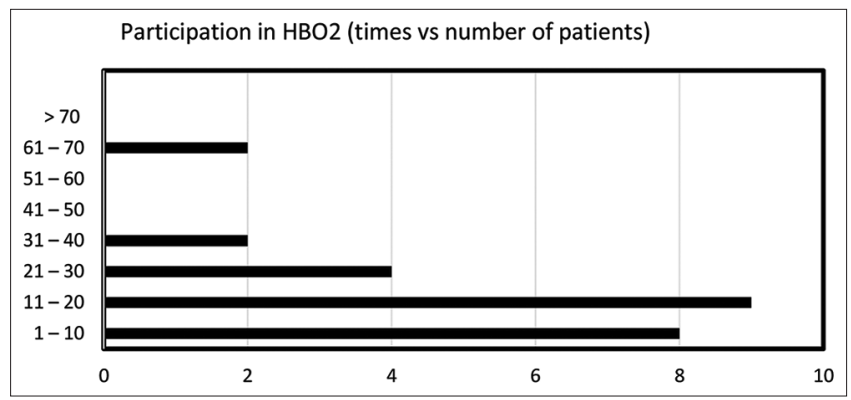

Figure 1: Chart type showing participation in hyperbaric oxygen therapy

At Lakesla, one package of $\mathrm{HBO} 2$ consists of 10 exposures to $\mathrm{HBO} 2$, given once daily, and the package is completed in 10 days. Figure 1 shows that the majority of GBS patients $(36 \%)$ received $11-20 \mathrm{HBO} 2$ treatments, $32 \%$ received $1-10 \mathrm{HBO} 2$ treatments, $16 \%$ received $21-30 \mathrm{HBO} 2$ treatments, and the remainder received more than $30 \mathrm{HBO} 2$ treatments. Two of the GBS patients received 61-70 HBO2 treatments (six-seven packages) solely because they were members (one navy, one army) and received $\mathrm{HBO} 2$ for free; they were free from duty due to their illness (Figure 1).

Around $60 \%$ of GBS patients felt their first positive changes after less than a week of receiving HBO2. Approximately $16 \%$ of GBS patients reported their first positive changes after 1-2 weeks of $\mathrm{HBO} 2$ and the remainder after more than 2 weeks of $\mathrm{HBO} 2$. However, we had two patients who did not feel positive changes: One died on the $4^{\text {th }}$ day; the other because there was no one takes the patient to hospital.

One indicator of clinical improvement after receiving $\mathrm{HBO} 2$ was the patient's ability to walk with or without assistance. Figure 2 shows that a large proportion of GBS patients (44\%) could walk with assistance after 2-3 weeks of receiving $\mathrm{HBO} 2$, and $32 \%$ of patients could walk without assistance after 4-12 weeks of receiving $\mathrm{HBO} 2$. Around $12 \%$ of GBS patients could walk without assistance in 1-2 weeks after receiving $\mathrm{HBO} 2$. However, two patients did not show any improvement and died on the $4^{\text {th }}$ day of treatment.

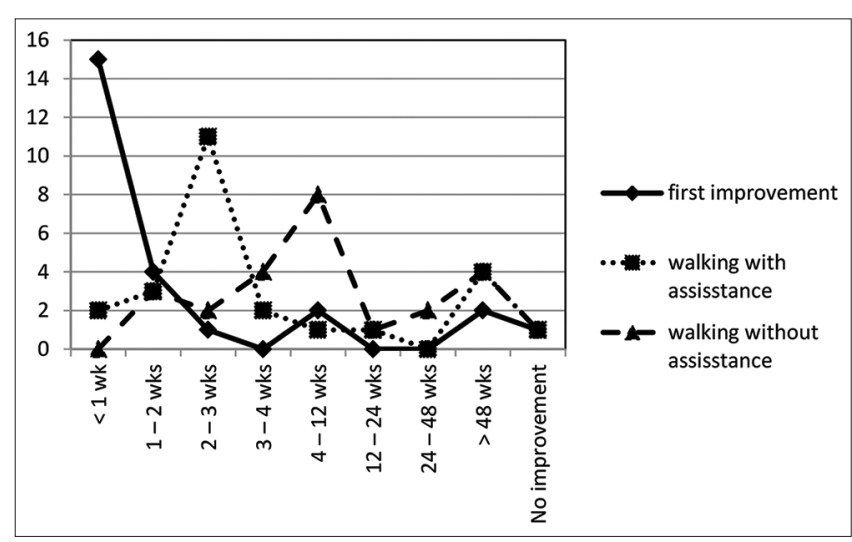

Figure 2: Line chart showing gradual improvement from the first improvement, walking with assistance until without assistance

\section{Discussion}

GBS is considered an acute immunemediated monophasic illness, with the worst condition occurring 2-4 weeks after the onset of the first symptoms [25], [26]. However, 6-7\% of GBS patients reported recurrence [26]. GBS is generally easy to diagnose - generally within a few days - based on the specific neurological clinical manifestations and progressive weakness. Patients usually present with symmetrical ascending muscle weakness along with areflexia. The initial symptoms of motor weakness are sudden, with some patients experiencing neck and back stiffness [27], [28]. Definitive diagnosis is obtained from cerebrospinal fluid testing and electromyography, which is effective after the $1^{\text {st }}$ week. Cerebrospinal fluid testing shows increase protein levels but with normal white blood cells count, whereas the nerve conduction study shows a slowing or blockage of conduction. Patients should be hospitalized and receive standard therapy including emergency treatment and definitive therapy, namely, IVIG and plasmapheresis [29].

HBO2 has been known as a therapy for diving-related diseases. Gradually, this therapy has been recognized as beneficial for wound healing. In the field of neurology, hyperbaric therapy is useful in central nervous system diseases (e.g., stroke) and peripheral nerve diseases (e.g., herniated nucleus pulposus) [23], [30]. GBS is one of the non-emergency indications for $\mathrm{HBO} 2$ [23]. Lakesla is an institution under the leadership of the Indonesian navy. At present, Lakesla carries the full costs of $\mathrm{HBO} 2$ for patients who come from the Indonesian soldier, the civil service of the Ministry of Defense (KEMHAN) and their core families. Therefore, $64 \%$ of GBS patients who underwent $\mathrm{HBO} 2$ were from this community. Private patient is the second community to have $\mathrm{HBO} 2$ at Lakesla. Despite paying fully out of pocket, private patients chose to have $\mathrm{HBO} 2$ because they wanted to hasten the improvement of their condition after receiving primary pharmacotherapy. 
Evidence for seasonal variation in GBS incidence has been contradictory [15]. At Lakesla, most GBS patients were admitted in February. Besides, the majority of GBS patients were from Surabaya, where the Lakesla is located, and $10 \%$ of patients were from out of town.

It is estimated that $25-40 \%$ of GBS patients worldwide have $C$. jejuni infection 1-3 weeks before the illness [31]. Other literature also states that two-thirds of GBS patients have a history of previous viral or bacterial infections and vaccination [2], [9], [11]. At Lakesla, a greater number of GBS triggers were preceding diarrhea 1-2 weeks earlier followed by common colds.

GBS has four subtypes: Acute inflammatory demyelinating polyneuropathy (AIDP), acute motor axonal neuropathy (AMAN), acute motor sensory axonal neuropathy (AMSAN), and MFS [32], [33]. AIDP is the most common subtype of these four constituting $85-90 \%$ of GBS cases [33]. AMAN and AMSAN are axonal forms of GBS that are most prevalent in Asia, and South and Central America [8].

Almost all GBS patients who came to Lakesla did not undergo electromyography, thus the data only described clinical symptoms. Most patients (72\%) clinically showed motor impairment only, which could be either AIDP or AMAN. Around $20 \%$ of patients showed motor and sensory impairment types, which could be AMSAN. There were $8 \%$ of patients who were diagnosed as having MFS, with symptoms of double vision and unbalanced walking.

In general, GBS patients who come to Lakesla have undergone definitive therapy at other hospitals, but they seek for HBO2 to aid their recovery. Around 36\% of patients have received IVIG therapy, $4 \%$ received corticosteroids, none received plasmapheresis, and $60 \%$ received other therapy.

There are three phases in the course of GBS disease, namely, progressive phase, plateau phase, and healing phase [34]. Few investigators have reported worsening of weakness after the onset of improvement or a plateau phase, called as treatment-related fluctuations, which is different from relapses [35], [36]. Clinical features, early recognition, and treatment contribute in the prognosis of GBS [17], [18]. Neurological symptoms can persist for up to $20 \%$ of the patients and half of the patients experience severe disability. More than $80 \%$ experience severe fatigue that persists after resolution of other symptoms [29].

At Lakesla, $\mathrm{HBO} 2$ was administered as adjunctive therapy for GBS patients. The biomolecular mechanism of HBO2 for GBS patients was not clear, but some experimental studies have demonstrated improvement in the acceleration of cerebral microcirculation and oxygenation, metabolism, angiogenesis, and reduction in inflammation in stroke and non-stroke diseases [37], decreased lipid peroxidation, inhibition of leukocyte activation, and promotion of neuronal survival [38]. From 2016 to 2019, around $60 \%$ of GBS patients at Lakesla felt their first positive changes in less than a week after receiving $\mathrm{HBO} 2,44 \%$ of GBS patients walk with assistance after 2-3 weeks receiving $\mathrm{HBO} 2$, and $32 \%$ walk without assistance after $4-12$ weeks receiving $\mathrm{HBO} 2$.

We observed that a total of eight patients who participated in hyperbaric therapy for less than 1 week also experienced the first changes at less than 1 week. At between 1 and 3 weeks, these patients could walk with support and were able to walk unaided within 1 month. This is quite surprising considering that half of the patients in this group come with the ability to perform only adduction abduction despite receiving IVIG therapy. Another 12 patients (five came in the interval of 8-14 days, seven came in the interval of 15-21 days) showed the first improvement in less than 2 weeks, walking with support in less than 1 month, and without support in less than 3 months. We also found one patient who came with hemiplegia and remained for 1 month without receiving IVIG therapy, experiencing changes in the $1^{\text {st }}$ month, walking with help in the $2^{\text {nd }}$ month, and walking without assistance in the $4^{\text {th }}$ month. Two patients with MFS experienced very good clinical improvement. Even though they had received IVIG therapy for 5 days, they still complained of double vision and ataxia. After 5 days following $\mathrm{HBO} 2$ therapy, on the $2^{\text {nd }}$ day, they reported that their double vision was greatly reduced and they were able to use their cellular phones. In less than 2 weeks, they were able to walk without help.

Unfortunately, we observed four patients who showed no improvement more than 21 days after the first symptom of GBS. Two had undergone IVIG therapy, but did not finish the first package of HBO2 therapy (fewer than 10 treatment). In these four patients, we observed their first improvement from 3 weeks to 12 months after treatment. Eighteen month later, they all still walked with assistance.

The use of definitive therapy such as IVIG and plasmapheresis can increase the cost of treatment up to 5-10 times. Therefore, most patients followed all hyperbaric therapy procedures in one to two packages (10-20 times) in an orderly manner. Some patients discontinued hyperbaric therapy because they felt improvement and wanted to have other therapies (physiotherapy and acupuncture) that were closer to their homes.

The GBS mortality rate ranging between $1 \%$ and $18 \%$ [21], [22] and predominantly occurred in the elderly and severely affected patients, especially during the recovery phase [21]. At Lakesla, 2 patients $(8 \%)$ died, one due to disease progression in the $4^{\text {th }}$ day of treatment and the other died 3 months later.

There are limitations in this study. This study only presents data with a very small population of GBS patients who come to the hyperbaric installation in Lakesla. This is because the GBS population is small. Of the few, only a few are aware of $\mathrm{HBO} 2$ therapy. 
According to all neurology's textbook, the main therapy for GBS is not HBO2. Likewise in the hyperbaric consensus, GBS is not included in the indications for therapy. In Indonesia, the majority of hyperbaric chambers are owned by Naval hospitals or hospitals that have underwater workers.

With experience at Lakesla over the past 3 years, it can be observed that $\mathrm{HBO} 2$ is beneficial for the clinical improvement of GBS patients. It is tempting to give $\mathrm{HBO} 2$ therapy as an adjuvant for GBS, when the patient cannot afford IVIG and the patient has no absolute contraindications to $\mathrm{HBO} 2$ therapy. With the hope of high interest in taking HBO2 therapy, of course, more samples can be taken. So that in the future, we can generalize the benefits of $\mathrm{HBO} 2$ in GBS cases.

\section{Authors' Contributions}

1. Ni Komang Sri Dewi Untari: Conceptualization, methodology, formal analysis, investigation, data curation, original draft preparation, review, and editing

2. Kurnia Kusumastuti: Methodology, investigation, and review

3. M. Guritno Suryokusumo: Methodology, investigation, and review

4. I Ketut Sudiana: Methodology, validation, and review.

\section{References}

\section{Conclusion}

At Lakesla, GBS was more common in males than females; the most common age group was 20-30 years. Clinical manifestations at admission were predominantly motor impairment in the form of muscle weakness in both legs. The prognosis of GBS patients who underwent $\mathrm{HBO} 2$ was generally good, even though $8 \%$ of patients died due to disease progression. Standard therapy (IVIG and plasmapheresis) has been carried out in the majority of patients, but the patients still did not experience complete motor function. Most GBS patients felt their first positive changes within the $1^{\text {st }}$ week, walked with assistance in 2-3 weeks, and walking without assistance in 4-12 weeks after receiving $\mathrm{HBO} 2$. We were not going to say that $\mathrm{HBO} 2$ gonna be replacing IVIG and plasmapheresis as standard therapy. Examining the GBS patients based on all the clinical changes, we hope that $\mathrm{HBO} 2$ could be an adjunctive therapy for GBS in Indonesia.

\section{Acknowledgments}

I would like to thank to Lakesla for providing the facility to conduct this research.

\section{Ethical Statement}

The Ethics Committee of Naval Health Institute, Indonesian Navy stated that this study was feasibly approved the study (Animal Ethical Clearance Certificate No.009/AECC/NHI/IX/2019).
1. Head VA, Wakerley BR. Guillain-Barré syndrome in general practice: Clinical features suggestive of early diagnosis. $\mathrm{Br}$ J Gen Pract. 2016;66(645):218-9. https://doi.org/10.3399/ PMid:27033501

2. St Charles JL, Bell JA, Gadsden BJ, Malik A, Cooke H, van de Grift LK, et al. Guillain Barré syndrome is induced in non-obese diabetic (NOD) mice following campylobacter jejuni infection and is exacerbated by antibiotics. J Autoimmun. 2017;77:11-38. https://doi.org/10.1016/j.jaut.2016.09.003

PMid:27939129

3. Yuki N, Hartung $H$. Guillain-Barré syndrome. N Engl J Med. 2012;366(23):2294-304. https://doi.org/10.1056/ NEJMra1114525

PMid:22694000

4. Dimachkie MM, Barohn RJ. Guillain-Barré syndrome and variants. Neurol Clin. 2013;31(2):491-510. https://doi. org/10.1016/j.ncl.2013.01.005

PMid:23642721

5. Wakerley BR, Yuki N. Infectious and noninfectious triggers in Guillain-Barré syndrome. Expert Rev Clin Immunol. 2013;9(7):627-39. https://doi.org/10.1586/17446 $66 \times .2013 .811119$

PMid:23899233

6. Poropatich KO, Walker CLF, Black RE. Quantifying the association between campylobacter infection and GuillainBarre syndrome: A systematic review. J Health Popul Nutr. 2010;28(6):545-52.

PMid:21261199

7. Tam CC, O'Brien SJ, Rodrigues LC. Influenza, campylobacter and Mycoplasma infections, and hospital admissions for Guillain-Barré syndrome, England. Emerg Infect Dis. 2006;12(12):1880-7. https://doi.org/10.3201/eid1212.051032 PMid:17326939

8. Vucic S, Kieman MC, Cornblath DR. Guillain-Barré syndrome: An update. J Clin Neurosci. 2009;16(6):733-41. https://doi. org/10.1016/j.jocn.2008.08.033 PMid:19356935

9. Nafissi S, Vahabi Z, Ghahar MS, Amirzargar AA, Naderi S. The role of cytomegalovirus, haemophilus influenzae and epstein barr virus in Guillain Barre syndrome. Acta Med Iran.

PMid:23852841 bjgp16X684733 2013;51(6):372-6. 
10. Dahbour SS. Clinical experience with Gullain Barre syndrome over a 6-year period in one hospital in the Middle East. Jordan Med J. 2009;43(4):280-5.

11. Barbi L, Coelho AV, de Alencar LC, Crovella S. Prevalence of Guillain-Barré syndrome among Zika virus infected cases: A systematic review and meta-analysis. Braz J Infect Dis. 2018;22(2):137-41. https://doi.org/10.1016/j.bjid.2018.02.005 PMid:29545017

12. Cao-Lormeau VM, Blake $A$, Mons $S$, Lastère $S$, Roche $C$ Vanhomwegen J, et al. Guillain-Barré syndrome outbreak associated with Zika virus infection in French Polynesia: A casecontrol study. Lancet. 2016;387(10027):1531-9. https://doi. org/10.1016/S0140-6736(16)00562-6

PMid:26948433

13. Méndez N, Oviedo-Pastrana M, Mattar S, Caicedo-Castro I, Arrieta G. Zika virus disease, microcephaly and GuillainBarré syndrome in Colombia: Epidemiological situation during 21 months of the Zika virus outbreak, 2015-2017. Arch Public Health. 2017;75(1):65. https://doi.org/10.1186/ s13690-017-0233-5

PMid:29118981

14. Sejvar JJ, Baughman AL, Wise M, Morgan OW. Population incidence of Guillain-Barré syndrome: A systematic review and meta-analysis. Neuroepidemiology. 2011;36(2):123-33. https:// doi.org/10.1159/000324710

PMid:21422765

15. Webb AJS, Brain SAE, Wood R, Rinaldi S, Turner MR. Seasonal variation in Guillain-Barré syndrome: A systematic review, metaanalysis and Oxfordshire cohort study. J Neurol Neurosurg Psychiatry. 2015;86(11):1196-201. https://doi.org/10.1136/ jnnp-2014-309056

PMid:25540247

16. Candra E. GBS Patients Increase in Productive Age; 2012.

17. Zhang Y, Zhao Y, Wang Y. Prognostic factors of Guillain-Barré syndrome: A 111-case retrospective review. Chin Neurosurg J. 2018;4(1):1-9. https://doi.org/10.1186/s41016-018-0122-y

18. González-Suárez I, Sanz-Gallego I, Rodríguez de Rivera FJ, Arpa J. Guillain-Barré syndrome: Natural history and prognostic factors: A retrospective review of 106 cases. BMC Neurol. 2013;13:95. https://doi.org/10.1186/1471-2377-13-95 PMid:23876199

19. Patwa HS, Chaudhry V, Katzberg H, Rae-Grant AD, So YT. Evidence-based guideline: Intravenous immunoglobulin in the treatment of neuromuscular disorders: Report of the therapeutics and technology assessment subcommittee of the American academy of neurology. Neurology. 2012;78(13):1009-15. https:// doi.org/10.1212/WNL.0b013e31824de293

PMid:22454268

20. Lünemann JD, Nimmerjahn F, Dalakas MC. Intravenous immunoglobulin in neurology-mode of action and clinical efficacy. Nat Rev Neurol. 2015;11(2):80-9. https://doi.org/10.1038/ nrneurol.2014.253

PMid:25561275

21. vandenBerg $B, B$ unschoten $C$, van Doorn $P A$, Jacobs BC. Mortality in Guillain-Barré syndrome. Neurology. 2013;80(18):1650-4. https://doi.org/10.1212/WNL.0b013e3182904fcc PMid:23576619

22. Ng KK, Howard RS, Fish DR, Hirsch NP, Wiles CM, Murray NM, et al. Management and outcome of severe Guillain-Barré syndrome. QJM. 1995;88(4):243-50. https://doi.org/10.1093/ oxfordjournals.qjmed.a069055 PMid:7796073

23. Yan L, Liang $T$, Cheng $O$. Hyperbaric oxygen therapy in China. Med Gas Res. 2015;5(1):3. https://doi.org/10.1186/ s13618-015-0024-4

\section{PMid:25722849}

24. World Health Organization. ICD-10 Online Versions. Geneva: World Health Organization; 2016.

25. van Doorn PA. Diagnosis, treatment and prognosis of GuillainBarré syndrome (GBS). Presse Med. 2013;42(6):e193-201. https://doi.org/10.1016/j.lpm.2013.02.328 PMid:23628447

26. Notturno F, Kokubun N, Sekiguki Y, Nagashima T, de Lauretis A, Yuki N, et al. Demyelinating Guillain-Barré syndrome recurs more frequently than axonal subtypes. J Neurol Sci. 2016;365:132-6. https://doi.org/10.1016/j.jns.2016.02.053

PMid:27206890

27. Burns TM. Guillain-Barré syndrome. Semin Neurol. 2008;28(2):152-67. https://doi.org/10.1055/s-2008-1062261 PMid: 18351518

28. Abai S, Kim SB, Kim JP, Lim YJ. Guillain-Barré syndrome combined with acute cervical myelopathy. J Korean Neurosurg Soc. 2010;48(3):298-300. https://doi.org/10.3340/ jkns.2010.48.3.298 PMid:21082065

29. Walling $A D$, Dickson G. Guillain-Barré syndrome. Am Fam Physician. 2013;87(3):192-7.

PMid:23418763

30. Liska GM, Lippert T, Russo E, Nieves N, Borlongan CV A dual role for hyperbaric oxygen in stroke neuroprotection: Preconditioning of the brain and stem cells. Cond Med. 2018;1(4):151-66.

PMid:30079404

31. Tandel H, Vanza J, Pandya N, Jani P. Guillain-Barré syndrome (GBS): A review. Eur J Pharm Med Res. 2016;3(2):366-71.

32. Feasby TE, Hahn AF, Brown WF, Bolton CF, Gilbert JJ, Koopman WJ. Severe axonal degeneration in acute Guillain-Barré syndrome: Evidence of two different mechanisms? J Neurol Sci. 1993;116(2):185-92. https://doi. org/10.1016/0022-510X(93)90324-R

PMid:8336165

33. Asiri S, Altwaijri WA, Ba-Armah D, Al Rumayyan A, Alrifai MT, Salam $M$, et al. Prevalence and outcomes of Guillain-Barré syndrome among pediatrics in Saudi Arabia: A 10-year retrospective study. Neuropsychiatr Dis Treat. 2019;15:627-35.

34. Harms M. Inpatient management of Guillain-Barré syndrome. Neurohospitalist. 2011;1(2):78-84. https://doi. org/10.1177/1941875210396379

\section{PMid:23983841}

35. Kleyweg RP, van der Meche FGA. Treatment related fluctuations in Guillain-Barre syndrome after high-dose immunoglobulins or plasma-exchange. J Neurol Neurosurg Psychiatry. 1991;54(11):957-60. https://doi.org/10.1136/jnnp.54.11.957 PMid: 1800666

36. Ramakrishnan S, Mustare V, Philip M, Thennarasu K, Periyavan S. Treatment-related fluctuations in guillain barre syndrome and the conundrum of additional cycles of plasmapheresis. Ann Indian Acad Neurol. 2017;20(4):372-7. https://doi.org/10.4103/aian.AIAN_242_17 PMid:29184340

37. Zhai WW, Sun L, Yu ZQ, Chen G. Hyperbaric oxygen therapy in experimental and clinical stroke. Med Gas Res. 2016;6(2):111-8. https://doi.org/10.4103/2045-9912.184721 PMid:27867477

38. Bennett MH, Weibel S, Wasiak J, Schnabel A, French C, Kranke P. Hyperbaric oxygen therapy for acute ischaemic stroke. Stroke. 2015;46(5):e109-10. https://doi.org/10.1002/14651858. CD004954.pub3 